\title{
Massive Vena Cava Thrombus Associated With a Renal Tumor
}

\section{Trombo Maciço da Veia Cava Associado a Tumor Renal}

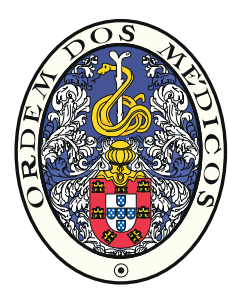

Sandro GASPAR $\square^{1}$, José DIAS ${ }^{1}$, Francisco MARTINS 1 , Tomé LOPES 1

Acta Med Port 2016 May;29(5):349-349 - http://dx.doi.org/10.20344/amp.6373

Keywords: Kidney Neoplasms; Venae Cavae; Venous Thromboembolism.

Palavras-chave: Neoplasias do Rim; Tromboembolia Venosa; Veias Cavas.

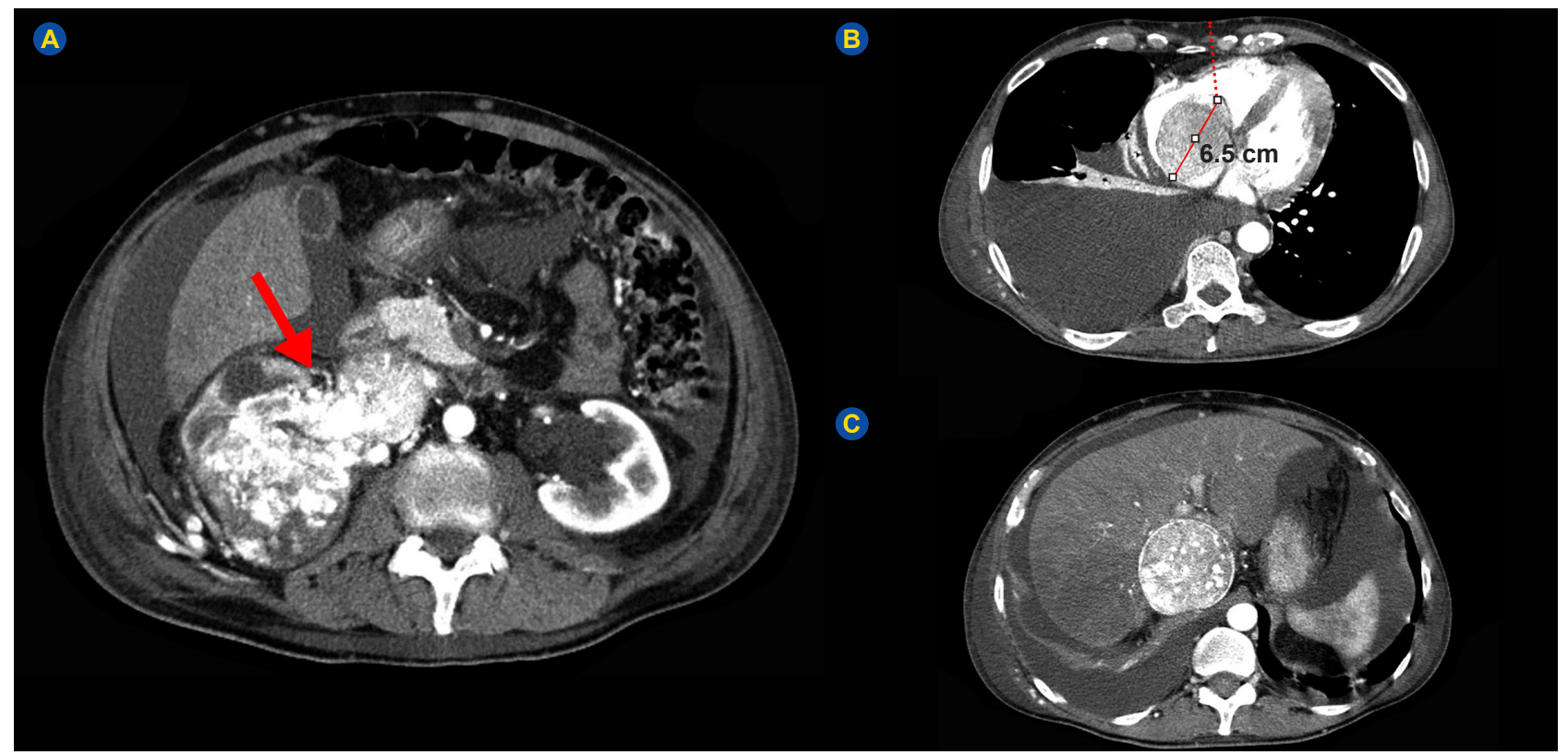

Figure 1 - Renal CT revealing a renal tumor with vascular invasion (A); Thrombus in right atrium totalling $6.5 \mathrm{~cm}$ in diameter (B); Retrohepatic portion of inferior venous tumor thrombus (C).

A 54-year-old male was referred to our institution harboring a renal tumor with an associated vena cava thrombus, complaining only of gross hematuria. Physical examination was unremarkable for findings. Ultrasonography showed a right renal mass with $7.5 \mathrm{~cm}$ of diameter, occupying most of the kidney.

Thoraco, abdominal and pelvic computed tomography (CT) detailed the mass to be, in fact, of $9 \times 6.5 \mathrm{~cm}$, with a rare finding: a very large vena cava luminal thrombus (Fig. 1A): a stage IV on the Mayo Clinical Classification, up to the right atrium (Fig. 1B) and down to the femoral veins.
The thrombus reached a diameter of $7 \mathrm{~cm}$ in it's subhepatic course (Fig. 1C), $6.3 \mathrm{~cm}$ in right atrium and $1.7 \mathrm{~cm}$ in the femoral veins.

Collateral venous circulation was evident. Advanced diseased precluded any surgical intervention, and patient's demise happened three months after first symptoms appeared.

Inferior vena cava thrombosis has been reported in $4-15 \%$ of cases of renal tumors, with extension to the right atrium in $1 \% .^{1,2}$ Long-term cancer-free survival up to 25 $65 \%$ following nephrectomy with tumor thrombectomy. ${ }^{3-5}$

\section{REFERENCES}

1. Furtado A, Graça B, Gonçalves FG, Ferrito F, Morais A, Santos AL. Carcinoma de células renais com trombo gigante na veia cava inferior - abordagem cirúrgica multidisciplinar. Rev Clin Hosp Prof Dr Fernando Fonseca. 2014;2:37-9.

2. Kaag MG, Toyen C, Russo P, Cronin A, Thompson RH, Schiff J, et al. Radical nephrectomy with vena caval thrombectomy: a contemporary experience. BJU Int. 2011;107:1386-93.

3. Klatte T, Pantuck AJ, Riggs SB, Kleid MD, Shuch B, Zomorodian N, et al. Prognostic factors for renal cell carcinoma with tumor thrombus extension. J Urol. 2007;178:1189-95.

4. Wotkowicz C, Wszolek MF, Libertino JA. Resection of Renal Tumors Invading the Vena Cava. Urol Clin N Am. 2008;35:657-71.

5. Kaushik D, Linder BJ, Thompson RH, Eisenberg MS, Lohse CM, Cheville JC, et al. The impact of histology on clinicopathologic outcomes for patients with renal cell carcinoma and venous tumor thrombus: a matched cohort analysis. Urology. 2013;82:136-41.

1. Department of Urology. Hospital Santa Maria. Centro Hospitalar Lisboa Norte. Lisboa. Portugal.

$\square$ Autor correspondente: Sandro Gaspar. sandrosilvagaspar@gmail.com

Recebido: 07 de março de 2015 - Aceite: 10 de outubro de 2015 | Copyright @ Ordem dos Médicos 2016 